\title{
STUDI KOMPARATIF PENGATURAN SISTEM KEPARTAIAN DI INDONESIA
}

\author{
Yusdar \\ Komisi Pemilihan Umum Kabupaten Bone \\ E-mail : yusdar.law@gmail.com
}

\begin{abstract}
This study aims to know and analyze the party system in Indonesia and compare then with party system in various countries. This type of research is a normative legal research. The approach used is the approach of legislation, conceptual approach and case approach.

The result of the research shows that the construction of party system arrangement in Indonesia shows the inconsistent arrangement and the existence of repetition of norm to formulation of legislation related to party and the implementation of parliamentary threshold as effort to create simple multi party is considered failed because facts happened in election 2014 with parliamentary threshold 3,5\% resulted in 10 political parties in parliament, in contrast to the 2009 elections with a $2.5 \%$ parliamentary threshold that resulted in 9 political parties in parliament.
\end{abstract}

Keywords: Comparative, Arrangement, Party.

\begin{abstract}
Abstrak
Penelitian ini bertujuan untuk mengetahui dan menganalisis sistem kepartaian di Indonesia serta mengkomparasikannya dengan sistem kepartaian di berbagai negara. Tipe penelitian ini merupakan penelitian hukum normatif. Pendekatan yang digunakan yaitu pendekatan perundang-undangan, pendekatan konseptual dan pendekatan kasus.

Hasil penelitian menunjukkanbahwakonstruksi pengaturan sistem kepartaian di Indonesia menunjukkan pengaturan yang inkonsistensi dan terdapatnya pengulangan norma terhadap pembentukan peraturan perundang-undangan terkait kepartaian serta penerapan parliamentary threshold sebagai upaya menciptakan multi partai sederhana dianggap gagal karena fakta yang terjadi pada Pemilu 2014 dengan parliamentary threshold 3,5\% menghasilkan 10 partai politik di parlemen, hal ini sangat kontras dengan Pemilu 2009 dengan parliamentary threshold 2,5\% yang menghasilkan 9 partai politik di parlemen.
\end{abstract}

Kata Kunci: Komparatif, Pengaturan, Kepartaian. 


\section{PENDAHULUAN}

Negara Indonesia adalah negara hukum. Hal tersebut telah dituangkan secara jelas dalam Pasal 1 ayat (3) Undang-Undang Dasar Negara Republik Indonesia Tahun 1945. Pengakuan kepada suatu negara sebagai negara hukum (governmental by law) sangat penting, karena kekuasaan negara dan politik bukanlah tidak terbatas, melainkan perlu pembatasan-pembatasan terhadap kewenangan dan kekuasaan negara dan politik untuk menghindari timbulnya kesewenang-wenangan dari pihak penguasa.

Dalam negara hukum, pembatasan terhadap kekuasaan negara dan politik haruslah dilakukan dengan jelas yang tidak dapat dilanggar oleh siapapun. Karena itu, dalam negara hukum, hukum memainkan peranannya yang sangat penting dan berada diatas kekuasaan negara dan politik. Karena itu pula-lah kemudian muncul istilah "pemerintah dibawah hukum" (government under the law). ${ }^{1}$

Salah satu tuntutan reformasi adalah amandemen terhadap UUD 1945. Tuntutan terhadap pelaksanaan amandemen UUD 1945 adalah tuntutan yang mempunyai dasar pemikiran teoritis konseptual dan berdasarkan pertimbangan empiris yaitu praktik ketatanegaraan Indonesia selama setengah abad. Kelemahankelemahan UUD 1945 secara konseptual memberi peluang lahirnya pemerintahan otoritarian. Penyelenggaraan negara berlawanan arah dari asas kedaulatan rakyat, asas negara berdasarkan atas hukum ditambah lagi proses penyelenggaraan pemilihan umum yang sangat didominasi oleh elit tertentu yang berlawanan dari konsep dasar yang di tetapkan dalam UUD 1945.

Prinsip kehidupan ketatanegaraan yang berkedaulatan rakyat ditandai bahwa setiap warga negara berhak untuk ikut aktif dalam setiap proses pengambilan keputusan negara. Oleh karena itu, dalam kajian hukum tata negara, pemilihan umum merupakan proses pengambilan keputusan oleh rakyat dalam keputusan ketatanegaraan sebagai sarana pengemban kedaulatan rakyat dalam

1. Munir Fuady. 2011. Teori Negara Hukum Modern (Rechtstaat).Cet. ke-2. RefikaAditama: Bandung. hlm.1 - 2. 
rangka pembentukan lembaga-lembaga perwakilan, disamping pemilihan umum memiliki fungsi rekrutment pemimpin dan legitimasi pelaksanaan kekuasaan. ${ }^{2}$

Keyakinan akan Pemilu sebagai instrumen demokrasi bukan hal baru dalam sejarah Indonesia merdeka. Bahkan rezim otokratis semisal Orde Baru pun tetap melaksanakan Pemilu secara berkala sebagai wujud pelaksanaan Demokrasi Pancasila. Kendatipun pelaksanaannya jauh dari kaidah demokrasi, namun pemilu telah menjadi instrumen terpenting yang membentuk keyakinan dan tradisi politik pada seluruh rakyat Indonesia akan signifikasi pemilu dalam kehidupan demokrasi. Pemilu seakan menjadi mantra bagi negara yang ingin dikategorikan sebagai negara demokratis. ${ }^{3}$ Tidak mengherankan jika selepas Orde Baru rakyat tetap menunjukkan sikap antusiasnya dalam mengikuti pemilu.

Tahun 2014 merupakan pemilu keempat yang dilaksanakan pada masa reformasi. Penyelenggaraan pemilu ini secara umum dapat dikatakan berjalan dengan lancar dan aman. Namun demikian, terdapat beberapa hal yang perlu diperhatikan dalam upaya evaluasi untuk perbaikan penyelenggaraan pemilu ke depan. Salah satu hal yang patut dikritisi adalah terkait dengan tujuan pemilu sebagai upaya legal untuk penyederhanaan sistem kepartaian.

Dalam setiap penyusunan undang-undang pemilu di Indonesia pada masa reformasi hampir dipastikan bahwa salah satu tujuan penyelenggaraan pemilu adalah terwujudnya sistem kepartaian yang multi partai sederhana. Walaupun demikian, masih belum jelas makna dari konsep multi partai sederhana yang hendak dicapai tersebut. Namun demikian, apabila konsep multi partai sederhana tersebut didasarkan atas jumlah partai politik yang ada, maka pengukurannya akan menjadi lebih terukur. Hal tersebut tentunya harus disesuaikan dengan kondisi sosio kultural di Indonesia. Indonesia dengan beragam kultur tentu saja tidak dapat disimplifikasi menjadi kuantitas kecil partai di Indonesia. Prinsip keterwakilan merupakan hal yang harus dijamin dalam konsep tersebut.

2. Dahlan Thaib. 2009. Ketatanegaraan Indonesia: Perspektif Konstitusional. Total Media: Yogyakarta. hlm. 103.

3. Karim menyebutnya sebagai token of membership. Lihat Abdul Gaffar Karim, dalam Sigit Pamungkas. 2009. Perihal Pemilu, Laboratorium Jurusan Ilmu Pemerintahan Fisipol UGM: Yogyakarta. 
Fakta yang terjadi pada pemilu legislatif tahun 2014 dapat dilihat dari jumlah partai politik yang ada atau mendapat kursi di DPR.Pemilu legislatif tahun 2014 telah menghasilkan 10 partai politik di DPR. Secara kuantitas partai, jelas bahwa pemilu legislatif tahun 2014 lebih besar jumlah partai politik di DPR dari pada hasil pemilu legislatif tahun 2009 yang hanya 9 partai politik. Apabila kita mengacu pada konsep multi partai sederhana dengan dasar kuantitas partai politik di DPR, jelah pemilu legislatif tahun 2014 telah gagal dalam upaya menyederhanakan partaipolitik.

Kegagalan penyederhanaan partai melalui pemilu legislatif tahun 2014 merupakan hal yang mengejutkan. Undang-Undang Nomor 8 Tahun 2012 bahkan telah meningkatkan parliamentary threshold menjadi 3,5\%. Kebijakan tersebut naik 1\% dibanding pemilu legislatif tahun 2009 yang hanya 2,5\%. Artinya bahwa kebijakan penaikan parliamentary threshold tidak berpengaruh signifikan dalam upaya penyederhanaan partai politik. Oleh karena itu, berbagai fakta di atas harus dijadikan sebuah bahan evaluasi dalam penyelenggaraan pemilu ke depan.

Dengan adanya momentum Putusan Mahkamah Konstitusi Nomor 14/PUU-XI/2013 yang menyatakan bahwa Pemilu Anggota DPR, DPD, dan DPRD serta Pemilu Presiden dan Wakil Presiden tahun 2019 dilaksanakan secara bersama dalam satu waktu dan diatur di dalam satu undang-undang harus dipersiapkan secara matang. Sebuah pelembagaan pemilu secara legal dengan kepentingan untuk mewujudkan sistem multi partai sederhana serta menjamin efektifitas penyelenggaraan sistem presidensiil haruslah dijadikan landasan utama dalam proses institusionalisasi tersebut.

Berdasarkan hal tersebut, penulis akan mengkaji lebih mendalam dalam bentuk karya ilmiah dengan judul Studi Komparatif Pengaturan Sistem Kepartaian di Indonesia. 


\section{PEMBAHASAN}

Desain pengaturan sistem pemilu di Indonesia pasca reformasi tahun 1999, 2004, 2009 dan 2014 selalu mengalami perubahan dan perkembangan yang signifikan. Perubahan paket Undang-Undang Politik dalam setiap pemilu ini membuktikan bahwa telah terjadi perubahan sosial politik di Indonesia yang menuntut diakomodasi dalam pemilu. Karena adanya pengaruh dan interaksi yang tidak terelakkan dari perkembangan masyarakat global. ${ }^{4}$

Sistem pemilu dengan penentuan calon terpilih berdasarkan suara terbanyak ini pada gilirannya melahirkan sistem pemilu liberal yang menitikberatkan pada kekuatan individu calon dan menafikan peran partai politik. Parpol hanya sekedar dijadikan alat dan kendaraan politik selebihnya kompetisi dalam pemilu terjadi antar individu calon. Padahal prinsip dasar sistem pemilu proporsional adalah mengutamakan peran parpol dan seharusnya kompetisi dalam sistem ini adalah kompetisi antar parpol. Sehingga tema kompetisi dalam kampanye adalah memperdebatkan ide, gagasan, visi, misi dan program parpol.

Menurut Undang-Undang Nomor 2 tahun 2011 tentang perubahan atas Undang-Undang Nomor 2 tahun 2008 tentang partai politik yang dimaksud dengan partai politik adalah organisasi yang bersifat nasional dan dibentuk oleh sekelompok warga Negara Indonesia secara suka rela atas dasar kesamaan kehendak dan cita-cita untuk memperjuangkan dan membela kepentingan politik anggota, masyarakat, bangsa dan Negara, serta memelihara keutuhan Negara Kesatuan Republik Indonesia berdasarkan Pancasila dan Undang-Undang Dasar Negara Republik Indonesia Tahun1945.

Hal yang menarik dalam kajian sistem kepartaian di Indonesia adalah adanya konstruksi pengaturan electoral formula yakni ditentukannya ambang batas parlemen (partlementary threshold) yang menurut penulis tidak sesuai dengan corak kebudayaan Indonesia serta berpotensi menafikkan esensi kedaulatan rakyat. Dalam ketentuan Pasal 208 Undang-Undang Nomor 8 Tahun 2012 bahwa partai politik peserta pemilu harus memenuhi ambang batas

4. Bechmann, Franz Von, Keebet von Bechmann, dan Anne Griffiths. 2005. Mobile People, Mobile Law, Exspanding Legal Relations in Contracting World, England, Ashgate. hlm. 2-3 
perolehan suara sekurang-kurangnya 3,5\% dari jumlah suara sah secara nasional untuk di ikutkan dalam penentuan perolehan kursi anggota DPR, DPRD Provinsi dan DPRD Kabupaten/Kota.

Ketentuan norma Pasal 208 pun akhirnya menjadi "banci" setelah di ajukan pengujian norma di Mahkamah Konstitusi, yang selanjutnya Mahkamah Konstitusi memutuskan bahwa pemberlakukan ambang batas parlemen 3,5\% hanya berlaku di tingkat DPR RI dan untuk di tingkat DPRD Provinsi dan DPRD Kabupaten/Kota dianggap tidak memiliki kekuatan hukum mengikat.

Berdasarkan hasil kajian tersebut, bahwa idealnya ketentuan Pasal 208 yang memberlakukan ambang batas perolehan suara tidak memuat lagi ketentuan untuk anggota DPRD Provinsi dan DPRD Kabupaten/Kota karena sebelumnya sudah ada putusan Mahkamah Konstitusi terkait pengujian Pasal 202 UndangUndang Nomor 10 Tahun 2008 tentang Pemilu Anggota DPR, DPD dan DPRD yang menyatakan bahwa parpol peserta pemilu yang memenuhi ambang batas perolehan sekurang-kurangnya 2,5\% dari jumlah suara sah secara nasional dapat diikutkan dalam penentuan perolehan kursi yakni Putusan Mahkamah Konstitusi Nomor 3/PUU-VII/2009 dan Putusan Mahkamah Konstitusi Nomor 52/PUU$\mathrm{X} / 2012$.

Selanjutnya untuk pemilu tahun 2019 norma tersebut masih termuat dalam ketentuan Pasal 414 ayat (1) Undang-Undang Nomor 7 Tahun 2017 Tentang Pemilihan Umum bahwa partai politik peserta pemilu harus memenuhi ambang batas perolehan suara paling sedikit $4 \%$ dari jumlah suara sah secara nasional untuk diikutkan dalam penentuan perolehan kursi anggota DPR.

Studi komparatif pada berbagai negara, ketentuan ambang batas yang diterapkan pada umumnya hanya satu, yaitu ambang batas penghitungan perolehan kursi yang dikenal dengan istilah electoral threshold. Sementara istilah parliamentary threshold tidak dikenal di dalam literatur-literatur pemilu bahkan dalam praktik penyelenggaraan pemilu di dunia.

Penggunaan istilah parliamentary threshold di Indonesia berawal dari Undang-Undang Nomor 12 Tahun 2003 ketika Indonesia menerapkan pertama kali ambang batas parlemen boleh tidaknya suatu parpol mengikuti pemilu 2004. 
Untuk mengartikan ambang batas ini digunakanlah istilah electoral threshold yang sebenarnya tidak tepat karena electoral threshold sebenarnya digunakan untuk mendefinisikan ambang batas penghitungan kursi di parlemen. Namun karena telah lazim, walaupun sebenarnya kurang tepat, istilah electoral threshold ini tetap digunakan. Kemudian pada pemilu 2009, Indonesia akhirnya menerapkan aturan electoral threshold dalam arti yang sebenarnya, yaitu ambang batas penghitungan kursi. Karena istilah electoral threshold telah terlanjur digunakan untuk mendefinisikan ambang batas kepesertaan dalam pemilu, akhirnya kemudian dimunculkan istilah baru untuk mengganti istilah electoral threshold yang terlanjur digunakan, istilah baru tersebut adalah parliamentary threshold.

Threshold dipraktikkan di negara-negara yang sistem kepartaiannya menganut sistem multi partai (multi party) dan sistem pemilunya menganut sistem proportional representation dan campuran. Tujuan penerapan threshold di semua negara rata-rata hampir sama yaitu untuk mengendalikan dan menyederhanakan sistem multi partai menuju kepada demokratisasi yang lebih berkualitas. Bahkan Indonesia, dengan sistem multi partainya yang telah mengarah kepada sistem "ultra multi partai" telah menerapkan dua threshold yaitu electoral threshold dan parliamentary threshold untuk menjaga kualitas demokrasi yang diharapkan.

Dari beberapa catatan dan literatur tentang pemilu berbagai negarayang menerapkan threshold di antaranya: Albania (3\%), Aljazair (5\%), Argentina (3\%), Armenia (5\%), Austria (4\%), Bulgaria (4\%), Burundi (2\%), Kroasia (5\%), Siprus (1,8\%), Denmark (2\%), Estonia (5\%), Jerman (5\%), Hongaria (5\%), Islandia (5\%), Israel (2\%), Italia (4\%), Latvia (5\%), Lithuania (5\%), Moldova (6\%), Montenegro (3\%), Mozambik (5\%), Selandia Baru (5\%), Palestina (2\%), Filipina (2\%), Rumania (5\%), Rusia (7\%), Rwanda (5\%), Serbia (5\%), Slovakia (5\%), Slovenia (4\%), Spanyol (3\%), Swedia (4\%), Taiwan (5\%), Turki(10\%), Ukraina (3\%) dan tentu saja Indonesia (2,5\%).

Berdasarkan kajian tersebut diatas, persentase ambang batas yang ditetapkan antara satu negara dengan negara lainnya berbeda-beda mengikuti 
dinamika politik internal masing-masing negara. Kisaran persentase minimal berkisar antara 1-10\%. Bahkan dalam negara tertentu penetapan persentase ambang batas juga cenderung berubah karena tingginya dinamika politik di negara bersangkutan. Israel misalnya, awalnya dalam pemilu 1992 ambang batas yang ditetapkan adalah $1 \%$, kemudian berubah menjadi $2 \%$ dalam pemilu berikutnya.

Begitu pula dengan Indonesia, dalam pemilu 1999 ambang batas perolehan suara ditetapkan $2 \%^{5}$, kemudian dalam Pemilu 2004 dinaikkan menjadi $2,5 \%{ }^{6}$. Dalam pemilu 2009 syarat untuk mengikuti pemilu prosentase ambang batasnya tetap 3\% ditambah parpol yang memiliki kursi di DPR periode 2004$2009^{7}$. Jika menyoal berapa angka prosentase paling ideal untuk menetapkan suatu threshold memang tidak ada ukuran bakunya. Praktik penetapan electoral threshold di hampir semua negara cenderung didasarkan pada konsensus politik yang didasarkan pada komitmen penyederhanaan partai di kursi parlemen. Dengan eletoral threshold maka kursi-kursi parlemen hanya akan diisi oleh partai yang memiliki representasi legitimate saja dengan ukuran electoral threshold.

Dengan demikian parlemen tidak akan terpecah-pecah ke dalam faksifaksi kecil yang bersifat fragmentatif dan kontraproduktif. Aturan electoral threshold ini memang cukup efektif dalam upaya membangun masa depan kepartaian yang lebih kuat dan sederhana. Namun jika penetapan electoral

5. Pasal 39 ayat (3) Undang-Undang Nomor 3 Tahun 1999 bahwa untuk dapat mengikuti Pemilihan Umum berikutnya, Partai Politik harus memiliki sebanyak 2\% (dua per seratus) dari jumlah kursi DPR atau memiliki sekurang-kurangnya 3\% (tiga per seratus) jumlah kursi DPRD I atau DPRD II yang tersebar sekurang-kurangnya di $1 / 2$ (setengah) jumlah propinsi dan di $1 / 2$ (setengah) jumlah kabupaten/kotamadya seluruh Indonesia berdasarkan hasil) Pemilihan Umum.

6. Pasal 9 ayat (1) Undang-Undang Nomor 12 Tahun 2003 bahwa untuk dapat mengikuti Pemilu berikutnya, Partai Politik Peserta Pemilu harus:

a. memperoleh sekurang-kurangnya 3\% (tiga persen) jumlah kursi DPR;

b. memperoleh sekurang-kurangnya $4 \%$ (empat persen) jumlah kursi DPRD Provinsi yang tersebar sekurang-kurangnya di $1 / 2$ (setengah) jumlah provinsi seluruh Indonesia; atau memperoleh sekurang-kurangnya 4\% (empat persen) jumlah kursi DPRD Kabupaten/Kota yang tersebar di 1/2 (setengah) jumlah kabupaten/kota seluruh Indonesia.

7. Pasal 315 Undang-Undang Nomor 10 Tahun 2008 bahwa Partai Politik Peserta Pemilu tahun 2004 yang memperoleh sekurang-kurangnya 3\% (tiga perseratus) jumlah kursi DPR atau memperoleh sekurang-kurangnya $4 \%$ (empat perseratus) jumlah kursi DPRD provinsi yang tersebar sekurangkurangnya di 1/2 (setengah) jumlah provinsi seluruh Indonesia, atau memperoleh sekurang-kurangnya $4 \%$ (empat perseratus) jumlah kursi DPRD kabupaten/kota yang tersebar sekurang-kurangnya di 1/2 (setengah) jumlah kabupaten/kota seluruh Indonesia, ditetapkan sebagai Partai Politik Peserta Pemilu setelah Pemilu tahun 2004. Pasal 316 huruf d menyatakan bahwa Partai Politik Peserta Pemilu 2004 yang tidak memenuhi ketentuan Pasal 315 dapat mengikuti Pemilu 2009 dengan ketentuan memiliki kursi di DPR RI hasil Pemilu 2004. 
threshold hanya didasarkan pada konsensus politik partai-partai besar belaka, tanpa diikuti pertimbangan dinamika dan realitas politik di dalam masyarakat dapat berakibat rendahnya derajat keterwakilan suara rakyat di parlemen. Contoh kasus dalam pemilu Rusia tahun 1998, ambang batas 7 \% yang diterapkan ditengah kuatnya politik aliran yang melahirkan ratusan partai baru telah berakibat 45\% suara rakyat tidak terwakili di parlemen. Begitu pula dengan Ukraina, walaupun ambang batas di negara tersebut lebih rendah yaitu 3\% namun telah membawa konsekuensi $22 \%$ suara rakyat tak terwakili.

Kasus yang paling mencolok adalah Turki karena ambang batas yang ditetapkan di negara tersebut paling tinggi sebesar 10\%. Tingginya ambang batas itu didasarkan pada fragmentasi politik internal Turki yang tak berkesudahan dari tahun 1960-an, sehingga ambang batas itu kemudian dibuat tinggi menjadi 10\% dalam pemilu 2002. Namun sayangnya aturan ambang batas tersebut ternyata tidak menghentikan fragmentasi politik yang terjadi, akibatnya dalam Pemilu 2002 sebanyak 45\% suara rakyat harus lenyap tak terwakili di parlemen.

Besarnya potensi hilangnya suara karena penerapan threshold memang disadari oleh hampir semua negara. Oleh karena itu rata-rata negara yang menerapkan threshold dalam menentukan prosentasenya selalu memilih berada dalam angka aman (kecil) berkisar antara 1-5\% (kecuali Turki dan Rusia).Bahkan Majelis Parlemen-Parlemen Eropa sempat membuat kesepakatan bersama untuk memberikan batasan threshold maksimal 3\% untuk meminimalisasi hilangnya suara pemilih di masing-masing negara.

Selain berpotensi hangusnya suara dalam jumlah besar, threshold juga cenderung menutup peluang bagi parpol-parpol kecil untuk mendapatkan kursi di parlemen sehingga seringkali penerapan threshold tersebut ditentang oleh banyak partai kecil. Oleh karena itu, beberapa negara mencoba memberikan solusi dengan cara membuat dua aturan threshold yaitu threshold bagi partai politik dan threshold bagi koalisi partai politik. Negara-negara tersebut antara lain Albania, Hongaria, Italia, Rumania dan Slovakia. Di Albania jika suatu partai perolehan suaranya tidak mencapai threshold 3\% diperbolehkan berkoalisi dengan partai lain, threshold koalisi partai yang ditentukan adalah 5\%. Di hongaria, 
threshold partai 5\% dan threshold koalisi partai 10\%. Sementara Italia, threshold partai politik $4 \%$ dan threshold koalisi partai 10\%. Untuk Rumania threshold partai politik 5\% dan threshold koalisi partai politik 8-10\%, dan Slovakia threshold partai politik 5\% dan threshold koalisi partai politik sebesar $7 \%$.

Disamping itu pemberlakuan threshold juga dinilai tidak mengakomodir keterwakilan kelompok minoritas di parlemen. Oleh karena itu, agar threshold tidak sampai mengakibatkan hilangnya suara minoritas (etnis, agama, gender, fungsional, dll) beberapa negara juga memberikan threshold khusus minoritas. Seperti negara Serbia misalnya, syarat threshold partai politik ditetapkan 5\%, namun khusus untuk kelompok minoritast threshold-nya dibuat lebih kecil yaitu 0,4\%. Agak berbeda dengan Serbia, Italia dalam upaya mengakomodasi kepentingan kelompok minoritas menggunakan lokal threshold $20 \%$, dimana kelompok minoritas tetap dapat diloloskan dari threshold dengan syarat di satu distrik bisa memperoleh suara $20 \%$ dari total suara distrik.

Selain Serbia dan Italia, Selandia Baru, Rumania dan Jerman juga menerapkan threshold husus dengan tujuan untuk mengakomodir minoritas namun dengan cara yang berbeda. Perbedaannya, jika batasan threshold minoritas Serbia dan Italia dilakukan dengan cara mengecilkan prosentase threshold atau membuat local threshold, di Selandia Baru, Rumania dan Jerman dilakukan dengan cara membuat ambang batas perolehan kursi. Penggantian threshold minoritas dari prosentase ke kursi di ketiga negara tersebut memang sangat dimungkinan karena ketiganya menggunakan sistem pemilu campuran (menggunakan mix member proportional) yang memadukan sistem proporsional (proportional party list) dan sistem distrik (first past the post).

Ambang batas perolehan kursi di ketiga negara tersebut berbeda-beda. Rumania misalnya, syaratnya minimal harus memperoleh 8 kursi (wakil distrik) jika tidak lolos threshold 5\% suara nasional. Sementara Jerman 3 wakil distrik jika tidak lolos threshold 5\% suara nasional. Yang paling ringan adalah Selandia Baru karena cukup memperoleh 1 wakil distrik jika tidak lolos threshold 5\% suara nasional. 
Berbagai cara untuk meminimalisasi hilangnya suara rakyat akibat threshold di beberapa negara diatas cukup urgen dan menarik dikaji khususnya dalam membangun threshold pemilu Indonesia ke depan. Paling tidak langkah-langkah modifikasi threshold dengan cara membuat threshold khusus koalisi, threshold khusus minoritas atau threshold perolehan kursi bagi negara penganut sistem pemilu campuran, sedikit banyak dapat membantu memberikan gambaran threshold paling ideal bagi Indonesia kedepan.

Philippe Nonet dan Philip Selznick mengungkapkan bahwa konflik kepentingan antar fraksi dalam perancangan pembentukan perundang-undangan dengan jelas mempengaruhi pembentukan undang-undang yang akhirnya mencederai prinsip rule of law, yang juga merupakan pelindung institusional yang menghendaki pemisahan antara kehendak politik dan putusan hukum. Hukum diangkat diatas politik, artinya hukum positif ditegakkan untuk menentukan bahwa persetujuan publik yang dibuktikan oleh tradisi dan proses konstitusional telah dijauhkan dari kontroversi politik. Oleh karena itu, otoritas untuk menafsirkan hukum harus dijaga sehingga terlindung dari perebutan kekuasaan dan tidak tercemar oleh pengaruh politik. ${ }^{8}$

Berkaitan dengan presidential threshold menurut Zudan Arif Fakrulloh ${ }^{9}$ harus dilihat norma dalam konstitusi yakni tentang persyaratan menjadi presiden dan tata cara pelaksanaan pemilihan presiden dan wakil presiden. Dalam perspektif ilmu lembaga dan pranata hukum melihat dua hal yang amat penting yaitu pertama, dari aspek substantive, tidak semua partai politik dapat memiliki kewenangan yang sama, misalnya partai yang memperoleh dukungan kursi $2 \%$ diberikan hak yang sama dengan partai politik yang mempunyai dukungan kursi $30 \%$. Dalam aspek different principles tentu saja hal itu tidak tepat. Kedua, terkait dengan legal policy Putusan Mahkamah Konstitusi Nomor 10/PUU-III/ 2005 yang intinya menyatakan pilihan kebijakan itu konstitusional.

\footnotetext{
${ }^{8}$. Philippe Nonet dan Philip Selznick. 2010. Hukum Responsif. Bandung: Nusa Media.

${ }^{9}$. Prof. Dr. Zudan Arif Fakrulloh, SH, MH merupakan salah satu saksi ahli yang diajukan oleh pihak pemerintah yang kesaksiannya diajukan secara tertulis dalam sidang mahkamah, keterangannya kemudian menjadi bagian dari inten putusan Mahkamah Konstitusi Nomor 51-5259/PUU-VI/2008, hlm. 117
} 


\section{PENUTUP}

\section{Kesimpulan}

Salah satu tujuan dari pemillihan umum adalah untuk penyederhanaan partai politik menuju sistem multi partai sederhana. Walaupun demikian, belum secara jelas maksud dari sistem multi partai sederhana tersebut. Akan tetapi, apabila dilihat dari jumlah partai politik hasil pemilu, dapat dikatakan pemilu 2014 gagal untuk menuju penyederhanaan partai politik, yaitu multi partai sederhana. Kenaikan ambang batas parlemen (parliamentary threshold) menjadi 3,5\% tidak menurunkan jumlah partai politik di parlemen. Hasil pemilu 2014 justru menambah jumlah partai politik di parlemen menjadi 10 partai. Hal ini berbanding terbalik dengan pemilu 2009 yang justru menempatkan 9 partai politik di parlemen dengan parliamentary threshold yang hanya $2,5 \%$.

\section{Saran}

Idealnya, kedepan upaya perbaikan penyelenggaraan pemilu adalah dengan merekonstruksi sistem pemilihan umum. Rekonstruksi sistem pemilihan umum dimaksudkan untuk menghadirkan sistem multi partai sederhana dan efektifitas sistem presidensiil serta tidak menggunakan ambang batas parlemen tetapi menggunakan konsep pembagian suara sah pada daerah pemilihan tersebut ke jumlah partai yang kemudian dibagikan secara persentase ke jumlah kursi pada daerah pemilihan tersebut.

\section{DAFTAR PUSTAKA}

\section{Buku}

Abdul Gaffar Karim, dalam Sigit Pamungkas. 2009. Perihal Pemilu, Laboratorium Jurusan Ilmu Pemerintahan Fisipol UGM, Yogyakarta.

Bechmann, Franz Von, Keebet von Bechmann, dan Anne Griffiths. 2005. Mobile People, Mobile Law, Exspanding Legal Relations in Contracting World, England, Ashgate.

Dahlan Thaib. 2009. Ketatanegaraan Indonesia: Perspektif Konstitusional. Total Media: Yogyakarta

Philippe Nonet dan Philip Selznick. 2010. Hukum Responsif.Nusa Media : Bandung.

Munir Fuady. 2011. Teori Negara Hukum Modern (Rechtstaat).Cet. ke-2. RefikaAditama: Bandung. 


\section{Peraturan Perundang-undangan}

Undang - Undang Dasar Negara Republik Indonesia Tahun 1945

Undang-Undang Nomor 12 Tahun 2003 tentang Pemilihan Umum Anggota DPR, DPD dan DPRD (Lembaran Negara Republik Indonesia Tahun 2003 Nomor 37, Tambahan Lembaran Negara Republik Indonesia Nomor 4277)

Undang-Undang Nomor 10 Tahun 2008 tentang Pemilihan Umum Anggota DPR, DPD dan DPRD (Lembaran Negara Republik Indonesia Tahun 2008 Nomor 51, Tambahan Lembaran Negara Nomor 4836)

Undang-Undang Nomor 2 tahun 2011 tentang Perubahan atas Undang-Undang Nomor 2 tahun 2008 tentang Partai Politik ( Lembaran Negara Republik Indonesia Tahun 2011 Nomor 8, Tambahan Lembaran Negara Republik Indonesia Nomor 5189)

Undang-Undang Nomor 8 tahun 2012 tentang Pemilihan Umum anggota DPR, DPD dan DPRD (Lembaran Negara Republik Indonesia Tahun 2012 Nomor 117, Tambahan Lembaran Negara Republik Indonesia Nomor 5316)

Undang-UndangNomor 7 Tahun 2017 tentang Pemilihan Umum (Lembaran Negara Republik Indonesia Tahun 2017 Nomor 182, Tambahan Lembaran Negara 6109)

\section{Putusan}

Putusan Mahkamah Konstitusi Nomor 51-52- 59/PUU-VI/2008 tentang Pengujian Pengujian Undang-Undang Nomor 42 Tahun 2008 tentang Pemilihan Umum Presiden dan Wakil Presiden terhadap Undang-Undang Dasar Negara Republik Indonesia Tahun 1945, 18 Februari 2009 